Article

\title{
Contribution of Geothermal Resources to Energy Autonomy: Evaluation and Management Methodology
}

\author{
Liliana Topliceanu * and Gabriel Petru Puiu \\ Engineering Faculty, "Vasile Alecsandri” University of Bacau, 157 Calea Marasesti, 600115 Bacau, Romania; \\ ppgabriel@ub.ro \\ * Correspondence: lili@ub.ro; Tel.: +40-234-542-411 \\ Academic Editor: Kent Hoekman
}

Received: 18 April 2016; Accepted: 15 July 2016; Published: 3 August 2016

\begin{abstract}
The development of renewable energy is one of the aspirations of the European Union energy policy, being generated by the struggle against climatic changes and by the intention of achieving a high rate of energy autonomy. In this context, geothermal energy is a viable solution which has been little exploited so far. Analysing the EU's dependence on imported energy, the paper provides a short review of the utilization of geothermal energy, of the advantages and of the problems raised by the exploitation of this resource. It also analyzes the availability of this resource in Romania and the contribution it can have towards the energy autonomy of local communities. The paper presents a particular methodology for calculating the energy autonomy. Using this methodology, one can obtain an energetic overview of the community or the area analyzed, can calculate the degree of energy autonomy and, based on the results achieved, a sustainable development strategy can be designed. The low enthalpy case study used emphasizes the way this methodology can be deployed and, moreover, allows an analysis of the contribution of geothermal energy to the degree of autonomy of the Romanian community.
\end{abstract}

Keywords: geothermal; methodology; energy autonomy; Romania; heating

\section{Introduction}

According to a simplistic, but much used definition, geothermal energy is the energy obtained from the heat of the Earth's core (the Earth's energy). Huge quantities of energy are generated and stored in the Earth's core, mantle and crust. Recent research estimates that inside the Earth's core temperatures may reach $6000{ }^{\circ} \mathrm{C}$ [1]. Concerning the continental crust, the temperatures typically range between $200{ }^{\circ} \mathrm{C}$ and $400{ }^{\circ} \mathrm{C}$ [2] but, according to other estimations, the temperature at the basis of the continental crust can also reach $1000{ }^{\circ} \mathrm{C}$ [3]. The transfer of this energy to the surface is made mainly by conduction, with a value which depends on local geothermal gradient. The analyses made by specialists consider that the Earth's total thermal energy potential is of $12.6 \times 10^{24} \mathrm{MJ}$, while that of the crust is of $5.4 \times 10^{21} \mathrm{MJ}[4,5]$.

The main demonstrated advantage of geothermal energy exploitation is represented by its diminishing of greenhouse gas emissions. Studies have been conducted which have compared the production of the same amount of thermal energy through the burning of fossil fuels and through the use of geothermal energy. Thus, the use of geothermal energy for an energy amount of 1 million TJ/year leads to a reduction by approximately 100 million tons of $\mathrm{CO}_{2}$ /year [3].

The geothermal resources within the Earth can be classified according to several criteria: temperature, the state of the geothermal fluid, chemical composition, rock structure and properties such as porosity and permeability, extraction depth. Although technologies have constantly evolved, the most frequently exploited so far have been the hydro-geothermal resources. Such resources have 
been identified in 90 countries around the globe, of which 72 countries use the extracted energy directly for heat, and 24 countries use it for the production of electricity [3,6].

EU energy policy [7] for reducing greenhouse gas emissions and the targets set for 2020 and 2030, have triggered interest in the exploitation of renewable energy sources, however, despite the sudden improvement [8] registered during the last years, geothermal resources are still underexploited. The state or local authorities, as well as the private investors have preferred to invest in wind sources, solar sources, biomass or micro-hydroelectric plants and have been less interested in geothermal resources which involve higher costs, risks and difficulties in terms of legislation. A part of the "Earth's energy" is not accessible through present technologies, and even the energy which is now available is definitely far below the existing exploitation potential [6,9].

\section{EU Energy Imports and the Renewable Sources}

The effort of the EU towards developing the exploitation of renewable energy sources, effort triggered mainly by the concern about the effects of greenhouse gases on the climatic changes, also has a second objective which is as important as the first one-diminishing the dependence on energy imports.

The statistical data reported show that during the period of time 1995-2013 energy imports from outside the EU increased from $43 \%$ to $53.2 \%$ for the whole primary energy sources (Table 1, Figure 1) [8], these imports being generated by the economic growth, the population growth, the development of transports, etc. The structure of EU imports for 2013 by category of fuels can be seen in Figure 1a, being dominated by petroleum and its derivatives.

Table 1. EU-28 Energy Import Dependency by Fuel (\%) adapted from [10]. With permission from (C) European Union, 2015.

\begin{tabular}{ccccccc}
\hline Type of Fuel & $\mathbf{1 9 9 5}$ & $\mathbf{2 0 0 0}$ & $\mathbf{2 0 0 5}$ & $\mathbf{2 0 1 0}$ & $\mathbf{2 0 1 2}$ & $\mathbf{2 0 1 3}$ \\
\hline Total & 43.0 & 46.7 & 52.2 & 52.8 & 53.3 & 53.2 \\
Solid fuels & 21.5 & 30.6 & 39.4 & 39.5 & 42.2 & 44.2 \\
of which Hard Coal & 29.7 & 42.6 & 55.7 & 57.9 & 62.6 & 64.6 \\
Petroleum and product & 74.0 & 75.8 & 82.2 & 84.4 & 86.4 & 87.4 \\
of which Crude and NGL * & 73.0 & 74.5 & 81.3 & 84.77 & 87.9 & 88.1 \\
Natural Gas & 43.4 & 48.9 & 57.1 & 62.2 & 65.8 & 65.3 \\
\hline & * NGL-Natural Gas Liquid. & & &
\end{tabular}

After analyzing the results, it can be noticed that during the period of time 1995-2000 there was a growth rate of total imports of $3.7 \%$ compared to 1995 , followed by a leap to $5.5 \%$ during the period of time 2000-2005, as compared to the previous period, thus reaching up to $52.2 \%$ imports. It is interesting to notice the fact that during the following 11 years the growth rate of the imported raw materials for energy production drops drastically, thus increasing by only $1 \%$ compared to the value registered at the end of 2005. Another extremely interesting fact is that, for the first time, there is a reduction of the value of imports, thus being recorded a drop by $0.1 \%$ in 2013 compared to 2012 (Table 1).

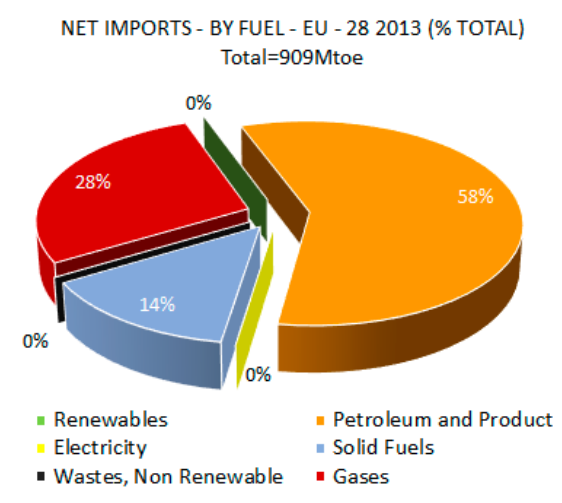

(a)

Figure 1. Cont. 


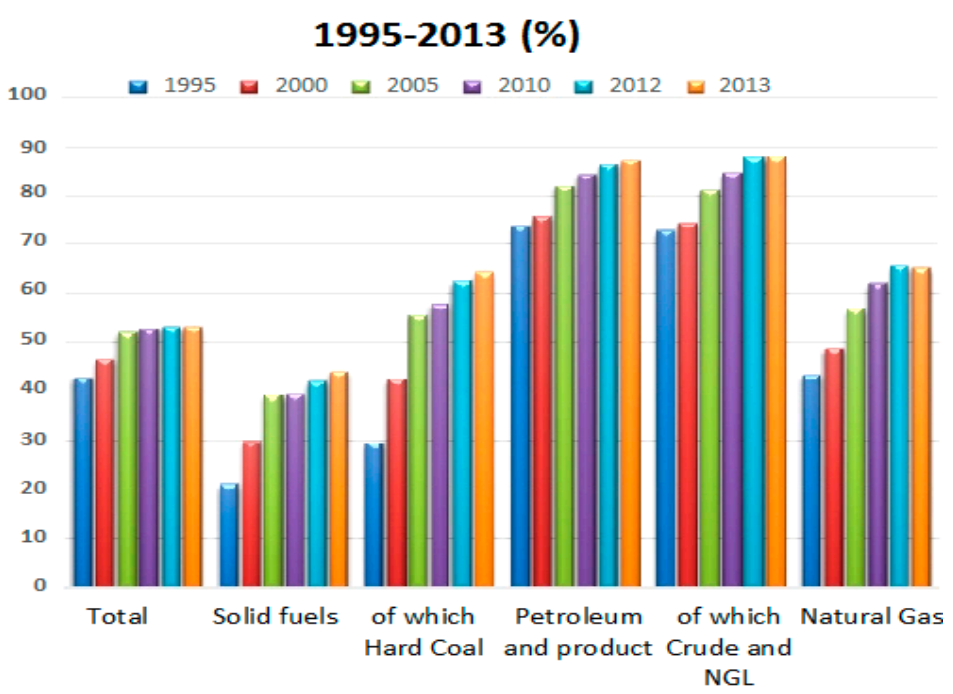

(b)

Figure 1. The dependency of the European Union on energy imports [10,11]. (a) Percentage distribution of imports by fuels for the year 2013; (b) Raw materials imported out of the total necessary amount. Adapted from [10] with the permisison from (c) European Union, 2015.

The period of time between 2005 and 2013 includes the economic crisis during which there was greater caution in investments and in the population consumption; however, it can be noticed that the growth rate for imports is still low during the whole period subjected to the analysis and it reaches an unprecedented value with the drop registered at the end of 2013. The drop in imports from 53.3\% in 2012 to $53.2 \%$ in 2013 is relatively small, but it marks an important change for the EU which will be confirmed by future statistics.

During the same period of time (1995-2013), there was an increase in the exploitation of renewable energy sources which represent $11.8 \%(12 \%)$ of the total primary energy sources at the end of 2013, starting from 5\% in 1995 (Figure 2) [10]. It can be observed that during the two years, 1995 and 2013, the primary energy production is approximately equal, being 1669 Mtoe in 1995 and 1665 Mtoe in 2013 , respectively.
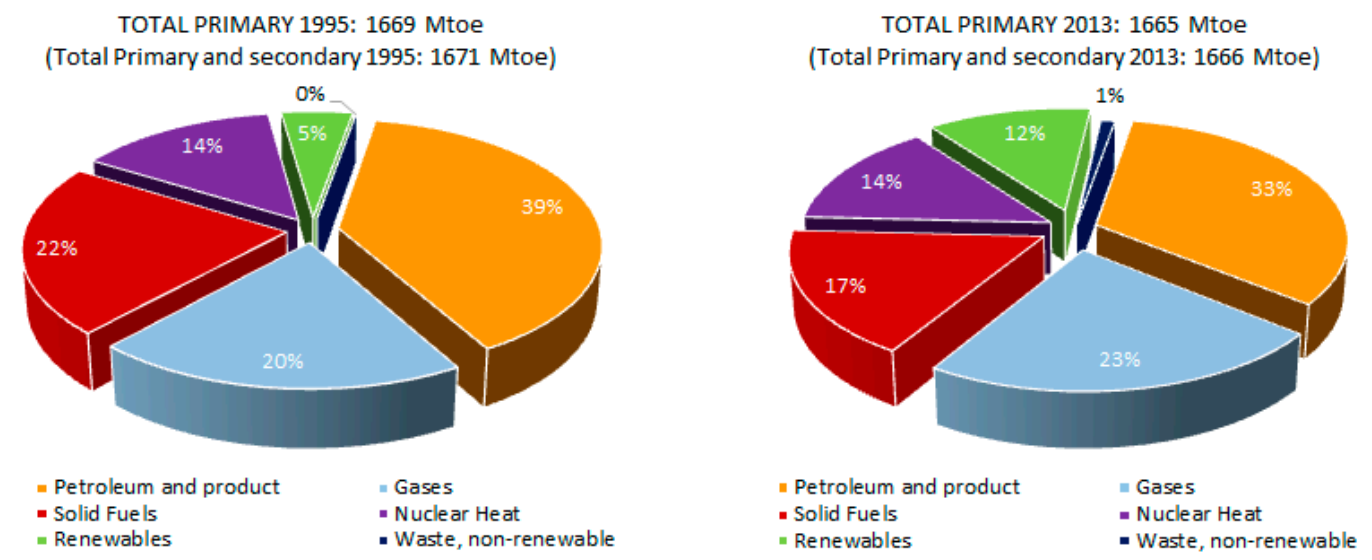

Figure 2. Energy Mix 1995 and 2013 (\%)—Primary Products Only [10,11]. Adapted from [10] with the permisison from (C) European Union, 2015.

Correlating these data [12] and also analyzing the structure of the raw materials used for energy, where a reduced consumption of petroleum and coal can be noticed, we can conclude that renewable energy sources have played an important role in maintaining a low import growth rate. It can be stated that the EU policy in the field of promoting the renewable energy sources is efficient not only in reducing the greenhouse gases, but also in diminishing the energy dependency. 
The percentage of different types of renewable sources is presented in Figure 3. Geothermal energy is the least developed renewable energy source, its contribution to the percentage of $12 \%$ of the primary production from renewable sources being of only $0.4 \%$.

The main advantage of geothermal energy, compared to other renewable sources, is its permanent availability, no matter the time of day, the season, the amount of precipitation or the wind intensity. Geothermal energy, whether it is easier or more difficult to exploit, or whether it requires more expensive or more accessible technologies for exploitation, is also available to all countries, everywhere.

The development of geothermal energy has been limited by the high costs required for its exploitation (which include the costs for exploration drilling), to which can be added the incoherent legislation concerning the licence for the exploitation of resources existing in many European countries.

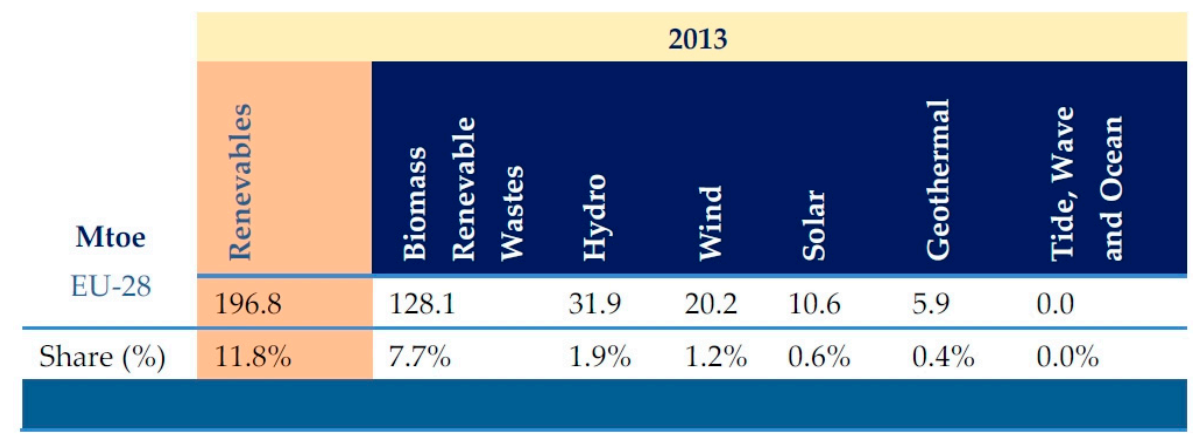

Figure 3. Use of renewable energy sources per type of energy [10,11]. Adapted from [10] with the permisison from (C) European Union, 2015.

The opponents of geothermal energy put forth as their main argument its impact on the environment [13]. However, neglecting the possible presence of some gases (which may occur in certain local situations [14]), it can be considered that the technologies for the extraction of geothermal energy have virtually no GHG emissions, the only potential source of emissions being the fluid extracted from the underground $[15,16]$. The exploitation of a modern binary power plant or a system for direct use of the fluid for heating purposes causes insignificant $\mathrm{CO}_{2}$ emissions $[17,18]$.

Complete studies carried out using the Life Cycle Assessment method, which takes into consideration the impact on the environment of a geothermal plant, starting with the building stage (the first drilling) and until it gets out of service, also emphasized its low impact on the environment. Thus, during the whole period the power plant is being used to generate energy, the $\mathrm{CO}_{2}$ emissions are below $80 \mathrm{~g}$ per kWhe and between 14 and $202 \mathrm{~g} \mathrm{CO}_{2} \mathrm{eq} / \mathrm{kWh}$ th for district heating systems [15], according to the type of technology used.

Other objections concern the possible occurrence of certain phenomena such as the degradation of the natural geothermal features in the area, the risk of contamination with arsenic, mercury, lithium and boron in case the fluids extracted were in contact with rocks containing such deposits. Micro earthquakes might occur during the drilling process [19]. Some of these risks can be avoided by reinjecting the fluid back into the geothermal system after it has been used and by preventing it from coming into contact with the air, while the microseismicity risks can be avoided by adopting suitable drilling technologies [13].

Despite these objections, we should not ignore the great potential of geothermal energy and its contribution to achieving the objectives of EU Sustainable Development Strategy [5], which requires that $20 \%$ of the energy used in Europe should come from renewable sources by 2020 , and that this percentage should be increased to $27 \%$ by 2030 .

At the end of 2014, in EU [8] there were 51 geothermal electricity plants (77 all over Europe, eight of which were built in Turkey during the previous year) with a total capacity of 945.96 MWe and ensuring 5.56 TWh of electric energy per year.

Speaking of thermal energy, its most efficient use is for central heating systems. Nowadays, there are 162 geothermal central heating systems in the European Union (247 in the whole of Europe, 
including Turkey), with a capacity of approximately 1.3 GWth and ensuring 4256 GWh of thermal energy [8]. In 2014, eight new systems located in France, Germany, Hungary and Italy were brought into service.

The old district heating stations based on fossil fuels which still exist in many towns can also be adapted and refurbished for geothermal energy, fact which can be achieved for a very competitive price [8]. As a matter of fact, a quarter of the EU population lives in areas where there is enough geothermal energy available for district heating [20], and from this point of view the area of the Pannonian basin deserves special attention.

Considering the still high percentage of natural gas imports on the level of 2013, it can be stated that extending the use of district geothermal heating systems will decisively contribute to reducing natural gas imports from outside the Union [21], while also reducing GHG emissions.

\section{Geothermal Energy in Romania}

Placed in the south-east of Europe, Romania has a complex geological structure which includes geothermal resources. The first signs of geothermal energy use on the territory of present-day Romania date from the time of the Roman Empire. Thermal springs were used for therapeutic and relaxation purposes, and remains of several such Roman baths (thermae romanae) have been discovered in Romania, some of which have been continuously used to this day.

Around 1885, the first drilling for developing a thermal water treatment facility was carried out in Baile Felix (Bihor County); however, the exploitation of geothermal resources for energetic purposes began in the 1960s [22,23], through a program meant to search for and exploit hydrocarbons.

Geothermal resources can be generally found close to the areas where tectonic plates meet. Those with higher enthalpy are located in the tectonic and volcanic areas behind the mountains that resulted from folding of the earth's crust after two tectonic plates collide, thus allowing the magma to come out along the faults/breaks through an eruption. The low enthalpy resources are also located close to the areas where the tectonic plates meet, but they are generally located in thin sedimentary basins [24].

In the case of Romania, most of the geothermal resources discovered are located in the porous permeable formations in the east of the Pannonian Basin (Figure 4). This area, situated on the western border of Romania (between the town of Satu Mare to the north and Timisoara City to the south), has an area of about $2.500 \mathrm{~km}^{2}$ and includes an aquifer situated at depths varying between 800 and $2400 \mathrm{~m}$, having temperatures between 50 and $85^{\circ} \mathrm{C}[22,25]$.

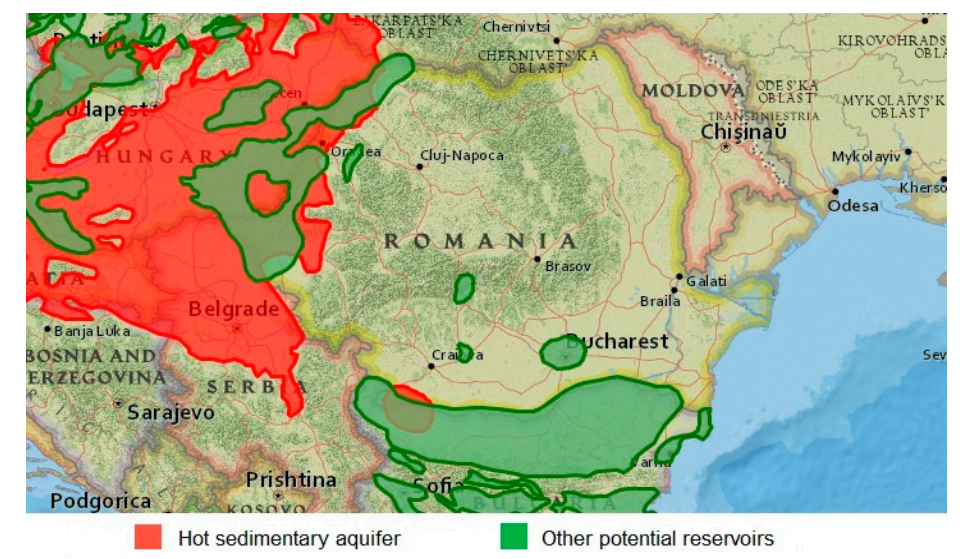

Figure 4. Distribution of the geothermal resources in Romania [20].

Also in the west of Romania, but with a different geological structure, lies the geothermal basin of Oradea (made up of Triassic limestone and dolomites) extending over $75 \mathrm{~km}^{2}$, situated at a depth of 2300-3200 $\mathrm{m}$ and having temperatures between 70 and $105^{\circ} \mathrm{C}$, the Felix Spa Cretaceous aquifer, connected to the Oradea basin, Beius geothermal deposit (also fissured Triassic calcite and dolomite), the Ciumeghiu geothermal reservoir, situated at a depth of about $2200 \mathrm{~m}$, with temperatures up to 
$105^{\circ} \mathrm{C}$, and the small basin of Bors, extending over $12 \mathrm{~km}^{2}$, also made up of fissured calcite rocks, which is a closed aquifer situated $2500 \mathrm{~m}$ deep and having temperatures of $130{ }^{\circ} \mathrm{C}[22,23]$.

In the south of Romania, other geothermal deposits are exploited: on Olt valley, in Cozia-Calimanesti area, there is a reservoir pressured to 30-33 bar, with a depth of 2700-3250 m, and with temperatures of $70-95^{\circ} \mathrm{C}$, while in the north of Bucharest there is Otopeni basin (reservoir) with wellhead temperatures of $58-84{ }^{\circ} \mathrm{C}$, situated $2000-3200 \mathrm{~m}$ deep.

All these low-medium enthalpy geothermal basins were identified and explored with about 250 drilled wells, thus determining a capacity of $480 \mathrm{MWt}$, considering a reference temperature of $25^{\circ} \mathrm{C}$. However, out of all the geothermal reserves known so far only $200 \mathrm{MWt}$ are being exploited using 96 wells [22].

The geothermal energy of these basins being of a hydro-thermal type, is used directly as thermal energy: individual space and district heating 39.7\%; recreation and health bathing $32.2 \%$; greenhouse heating $17.1 \%$; industrial process heat $8.7 \%$; fish farming and animal husbandry $2.3 \%$ [22].

Besides these low enthalpy resources, other research carried out during the last 25 years emphasized the existence of certain geothermal deposits with aquifers having temperatures of over $140^{\circ} \mathrm{C}$, which would enable them to produce electricity (Figure 5). Such areas can be found both in the north-west of Romania and inside the curve of the Carpathians.

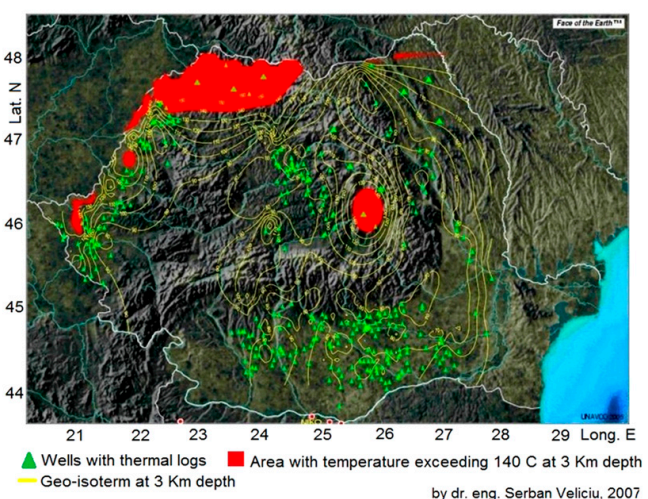

(a)

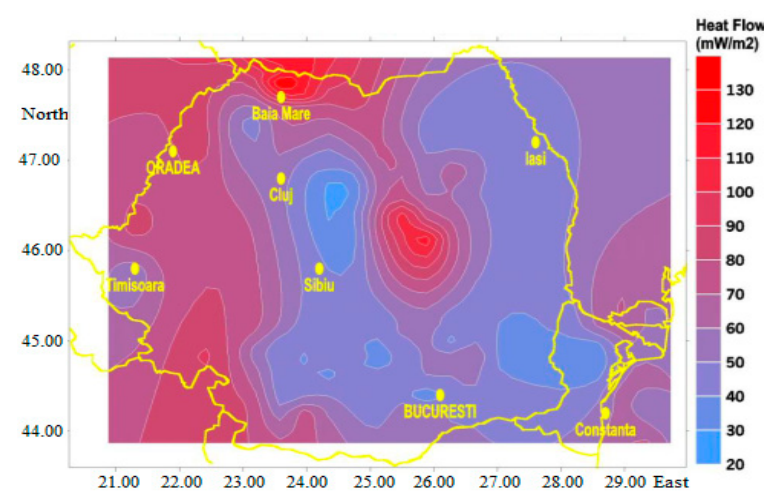

(b)

Figure 5. Position of the geothermal reserves in Romania [26] (a) Map of high temperature reserves;

(b) Terrestrial heat flow map of Romania.

A pilot installation for the conversion of geothermal energy into electric energy was implemented in 2012 in Oradea area. The power station has a capacity of $50 \mathrm{kWe}$ and it uses geothermal water [18].

Development of the geothermal potential in Romania was slow during the last few years, unlike the use of other types of renewable sources. Thus, from 2005 to 2014, only nine new wells were drilled, and these included not only the ones used for the extraction but also the ones for reinjecting the used water back into the aquifer, in the case of the already existing installations.

There are multiple reasons for this slow development, including the legislative issues (the slow process of licensing, legal incoherencies concerning the ownership over the resources, etc.) and the economic ones, the lack of interest manifested by the authorities and the difficult access to the new technologies.

The authors suggest that the lack of interest manifested by the authorities in supporting the exploitation of geothermal resources and reservoirs, exploitation which requires great cost and risk (especially during the first stages of the process) is also due to the fact that by 2014 Romania had already met the target set for 2020 - that $24 \%$ of the energy consumption should come from renewable sources.

The rising trend of investments in renewable energy registered in 2012 and 2013, as well as the financial efforts transferred to the population (because of the Green Certificates purchased by the producers of energy from fossil fuels), determined the Romanian state to make consecutive modifications of the support scheme for energy from renewable sources, by reducing the number of green certificates allotted for $1 \mathrm{MW}$ of energy. Thus, during the last two years, the investments in 
the large wind and solar farms dropped, while the interest in hydropower and especially in biomass increased, since these types of energy still get three green certificates for each MW.

Considering the fact that, besides all the aspects mentioned above, the wind and photovoltaic energy could produces some difficulties in the electricity transport and distribution network due to its fluctuating character, the national support policy encourages the exploitation of geothermal energy, which has no discontinuity problems and which can adequately meet the energy demand in certain areas.

According to the Romanian Law 220/2008, the energy from geothermal sources should get three green certificates for $1 \mathrm{MW}$.

The exploitation of renewable energy in general and of geothermal in particular is an excellent way of using the natural resources, of ensuring autonomy from energy companies and an opportunity for the local authorities to get involved and to ensure a certain level of economic stability and comfort standards to the population. This goal is attainable in many cases, especially for small communities where there are many renewable energy sources.

Before the future energetic plan can be developed, the local authorities need an energetic assessment of community and in the following paragraphs the algorithm of the methodology which can provide this type of evaluation is presented.

\section{Methodology Proposed for Energetic Evaluation of a Community}

The particular methodology, derived from the project Network of small RURal communities for ENERgetic-neutrality, (IEE/07/547/SI2.499065/2008), enables the diagnosis of a community from an energetic point of view. The knowledge concerning the demand of energy, the sources for covering this demand and the energy consumption for different sectors of activity, offers the communities the tool necessary for the future energetic strategy and for conceiving the Sustainable Energy Action Plan.

The method uses mainly two great categories of data: the energy consumption and the energy production on the level of the community [27]. By comparing these data, the degree of energy independence/autonomy of that community and the way in which it produces the energy necessary for its own proper functioning can be determined. Basically, the method can be applied to any administrative structure: a large or a small community, a neighbourhood, a county, a development region and through extrapolation, it can even be applied on national level. However, it is important to mention that the amount of data which have to be collected is proportional to the area where the methodology is applied and the accuracy of the assessment depends on the precision of these data.

The flow of information which has to be collected is presented in Figure 6.

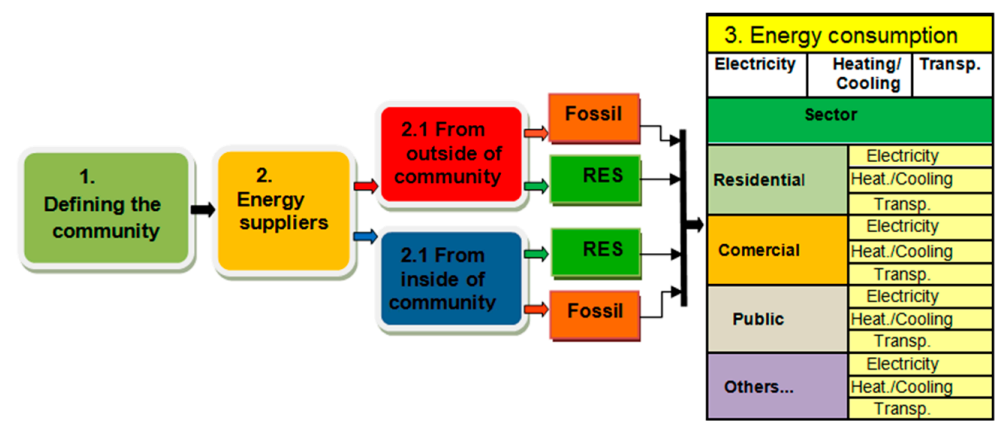

Figure 6. The chart of the data collection for energetic assessment.

Some explanations concerning the steps which must be taken are presented below, each methodology user being free to choose his/her own algorithm, the quality and the accuracy of the data collected being essential [28].

a Defining the community / area in which the methodology is applied.

This involves setting the physical boundaries of the community/area, the surface and the number of inhabitants, the sectors existing on that territory: residential, commercial, industrial, public services, 
transport, agriculture, forests, etc. In fact, it involves a thorough knowledge of the area which is going to be analyzed from the energetic point of view.

b Identifying all the suppliers and all the types of energy used in the area.

Here the major suppliers which provide energy through the grid and the small private producers that produce energy for their own use should be included. All the types of energy and fuels used will be catalogued: electricity, coal, coke, natural gas, wind energy, hydroelectric power, biomass, biogas, solar energy, geothermal energy, petrol, diesel oil, kerosene, etc. This inventory will record separately the energy produced within the community and the energy coming from outside its physical borders, from the great regional energy suppliers.

c Calculating the energy produced on community level from renewable sources.

It is important for the purpose of this analysis to identify separately the energy produced within the community or the area and the energy from renewable sources. It will later allow determination on the degree of autonomy of the area and, if it is desired, how "green" that community or area is.

d Setting the energy consumption by sector of activity and type of energy.

This stage is the most laborious and difficult one, but knowing the way in which a community uses energy is an important tool, guiding the future energetic policies of the community. Thus can be determined the areas which can and should be improved in order to increase the energetic efficiency, or the areas in which the demand can be met exclusively from local sources. Different sources can be used in order to collect these data: reports of the economic agents, statistics, bills or even surveys in case of the residential sector. All the energy and fuel consumption will be recorded separately for each sector specific to the community or the area: residential, public, industry, agriculture, etc., working as detailed as the analysis is meant to be.

e Setting the conversion factors for different types of energy sources, according to the calorific value/ the energy content and the unit of measure.

The collection of data concerning energy usually involves different units of measure: $\mathrm{kWh}$, litres for liquid fuels, $\mathrm{m}^{3}$ for wood, etc., and it is necessary to convert them into the same unit of measure. After all these steps, the information gathered is introduced in the excel form dedicated to this methodology. The first part of the table includes information concerning the energy consumption of the community (Figure 7), which is distributed on types of final consumers (Figure 8).

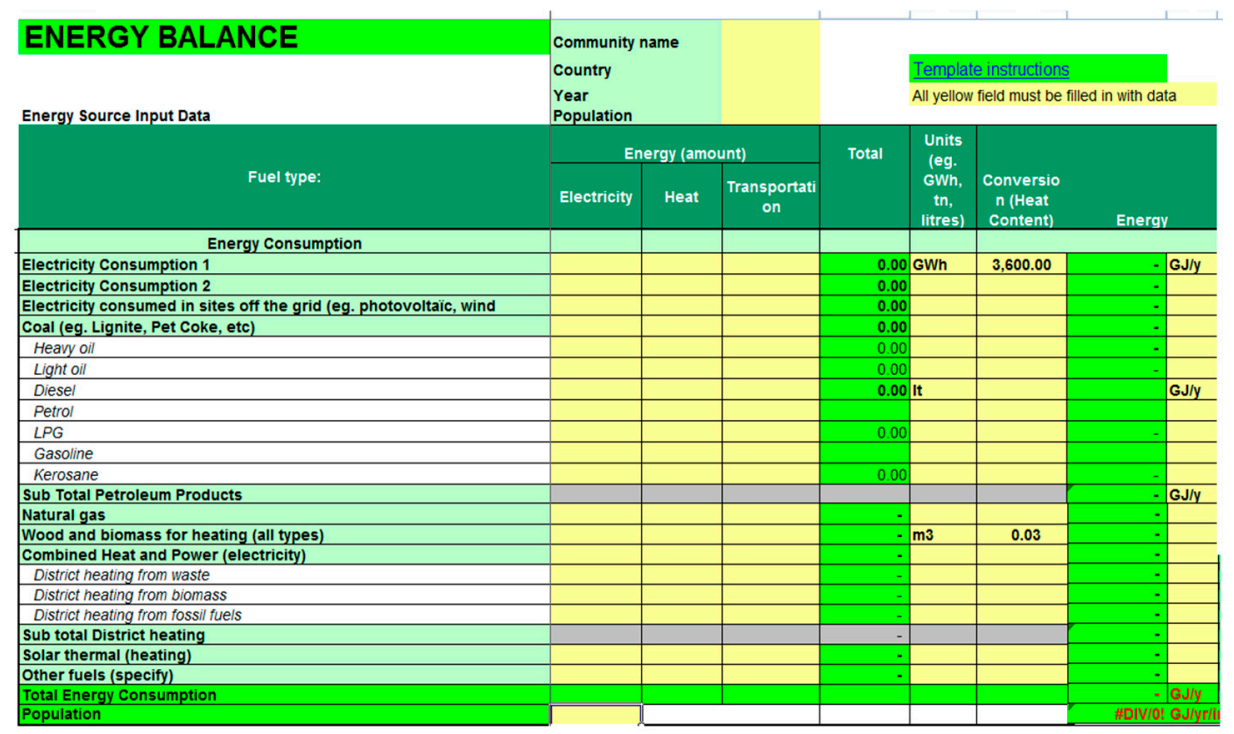

Figure 7. Energy consumption of the community. 


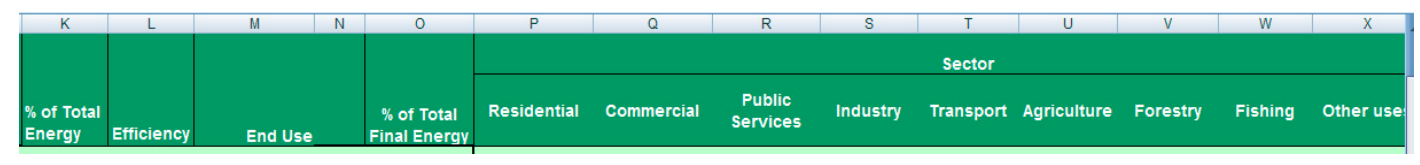

Figure 8. Distribution of the consumption on types of users.

According to the specific features of each community analyzed, new lines can be added to the template or existing ones can be modified or erased so as to adapt it as well as possible to the subject of the analysis. The second part of the table, having the same columns as the first part, includes the production of energy on community level (Figure 9) and all the renewable energy sources (RES) existing on the territory of that community are listed here.

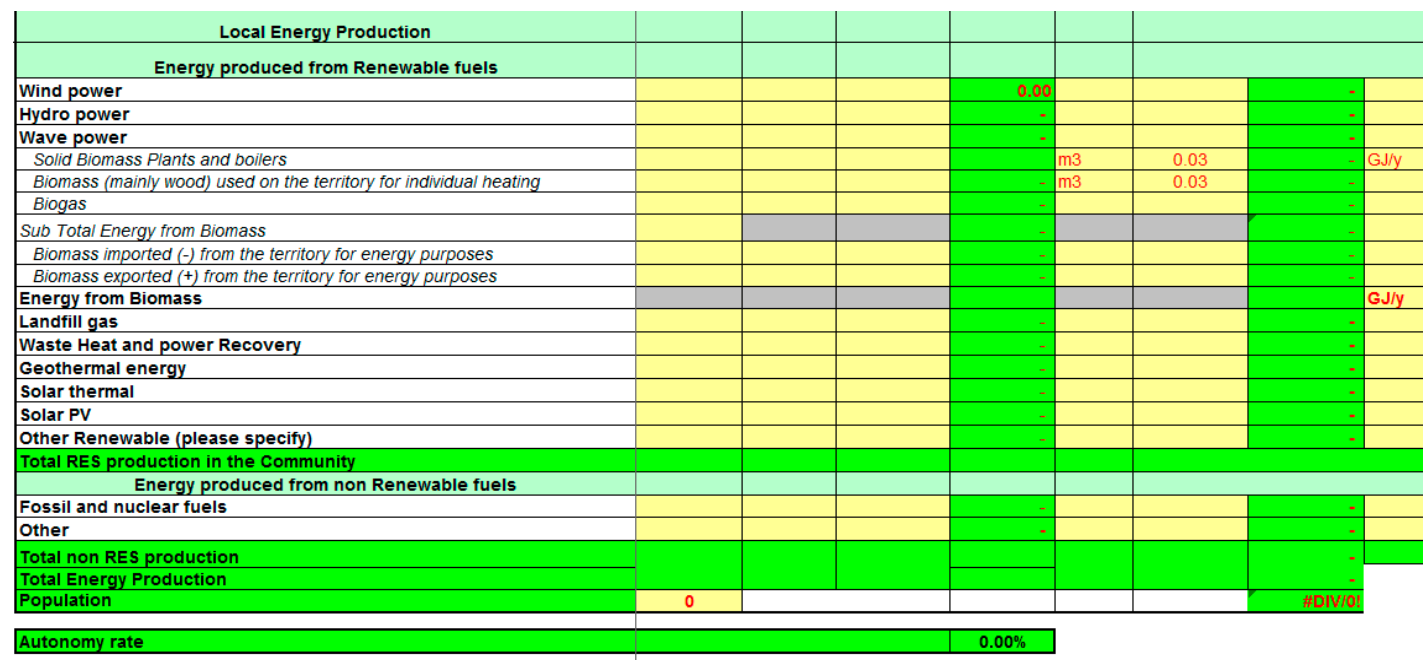

Figure 9. The local energy production.

According to the information collected and the way in which the form is filled out, the methodology can allow several types of analyses. For instance, we can determine the percentage of a certain type of energy in the total consumption, the percentage of a certain type of fuel out of all the fuels used, the report of consumption on different economic sectors or the percentage of a certain sector out of the total consumption of energy, for example.

\subsection{Case Study-Analysis of the Contribution of Geothermal Energy to a Community's Energy Autonomy}

Ensuring the energy demand from local or regional sources, reaching energy autonomy from the great regional suppliers and from the price they impose, is a challenge that many administrations have tried to turn into reality. It can be achieved in part by using the renewable energy available in that area. Following this line, the level of energy autonomy ensured within a small community by its renewable resources: first of all, the geothermal resource and then the biomass, should be analyzed.

\subsubsection{Defining the Community}

The town of Călimănesti was chosen as subject for this analysis. The town is situated in an area with a good geothermal potential, a resource which is exploited using a pre-existent district heating system. The system does not cover the whole demand of the town, and the exploitation of geothermal energy should be enhanced and improved, especially from the point of view of its environmental impact; however, it is a good example of the way in which the geothermal sources can contribute to the local energy autonomy and can reduce the financial efforts of the population.

Călimanesti is a set of small villages with the same administration, known in the touristic guidebooks as the Călimănești-Căciulata balneo-climateric resort. The community is situated in a very picturesque natural landscape, at the bottom of the Southern Carpathians, at the altitude of $260 \mathrm{~m}$, 
along both banks of the river Olt. The town is positioned $18 \mathrm{~km}$ north of Râmnicu Vâlcea, the county capital, and from the administrative point of view it is made up of the following communities: Calimanesti, Caciulata, Cozia, Seaca—situated on the right bank of Olt river, and Păuşa, Jiblea Veche, Jiblea Nouă—situated on the left bank (Figure 10). The town spreads over 10.632 ha, 264 ha of which are built-up area [29].

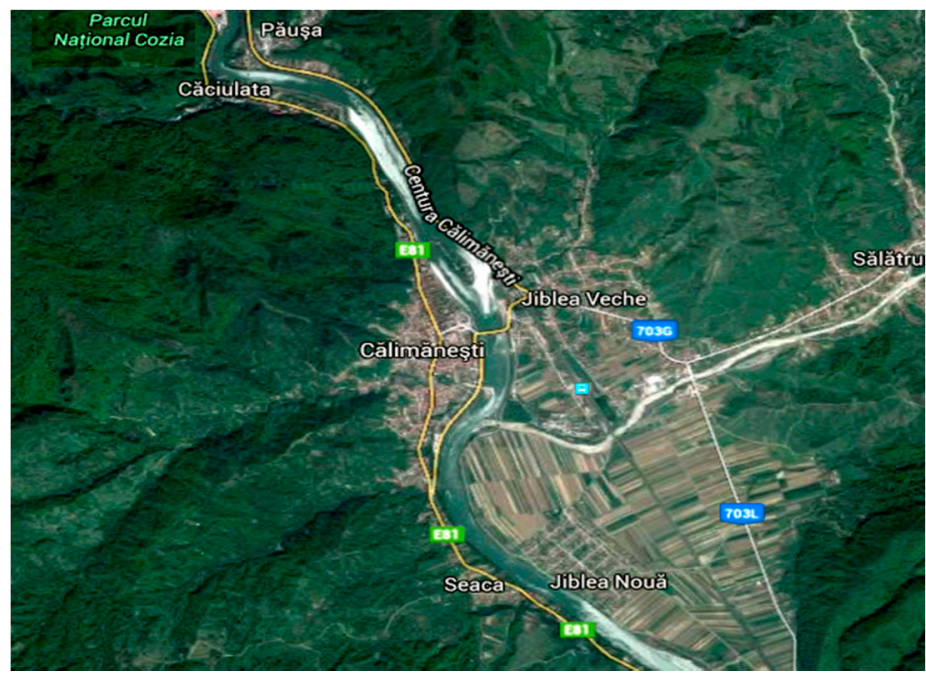

Figure 10. Position and components of Călimănești town (from Google maps).

At the time when this study was carried out, according to the official documents of the town hall, 8738 people resided here. However, according to the results of the 2011 census, the stable population of the town was of 7622 people, which means that $12.77 \%$ of the people had migrated abroad or to other richer areas of the country, the town being situated, from this point of view, below the county average of $15.5 \%$ representing the population who left their homeland.

The town is well-known for its mineral springs with variable chemical compositions and temperatures, which have been used for therapeutic purposed ever since the 19th century. The climate is continental, characteristic for the Subcarpathian depressions, with a yearly average temperature of $9.7^{\circ} \mathrm{C}$, the average temperature of July being of $19^{\circ} \mathrm{C}$ and of January $-1.5^{\circ} \mathrm{C}$. The average yearly precipitation is of $750-800 \mathrm{~mm}$, the sunshine duration is of 110 days and the annual relative humidity is between $60 \%$ and $80 \%$.

The surface resources are represented by the broadleaf forests on the surrounding mountains, as well as by the culture of walnut, chestnut, plum, apple trees and grape vine. The underground resources are the mineral and geothermal waters which constitute the foundation for the economy and the tourism in the area.

As to the workforce, out of the total 3158 active population, $38.9 \%$ work in the field of trade, $16.5 \%$ are in the hospitality and food service sector, $17 \%$ in industry, $6.7 \%$ in education, $6.3 \%$ in health and social services and then, in various percentages under $6 \%$ are in the field of: transport, constructions, information and communication, public administration, financial sector and cultural activities. The data presented are for 2011 but the situation remains relatively static. At the time of this study, the town had a number of 3460 conventional dwellings, four infant schools, four schools and one high school.

\subsubsection{Energetic Assessment of the Community}

The data necessary for applying the methodology presented in the previous paragraphs were collected by referring to the official documents, the statistical reports and, in case it was necessary, by consulting directly the population in the area. 
The electric energy supply for the community comes from the national energy grid and in 2011 a consumption of $6.63 \mathrm{GWh}$ was registered. As to the thermal energy, Călimănești town benefits from several types of sources: geothermal, natural gas and biomass.

The extraction of geothermal energy is carried out using three wells drilled at depths of $3250 \mathrm{~m}$ (Călimănești 1009 well and Caciulata 1006 well) and of 2641 m (Cozia 1008 well). The three wells are situated about 1-1.2 km apart, on the right bank of the river Olt. Using these wells, the hot water is extracted at temperatures between 92 and $96{ }^{\circ} \mathrm{C}$, in a mixture with gases $(1-1.5$ cubic meter of gas, in normal physical state, per 1 cubic meter of water). The available flow of the three wells is $50.41 / \mathrm{s}$, the equivalent of a potential of $13.2 \mathrm{MW}$ in case the exploitation of the geothermal water were carried out at a temperature up to $30^{\circ} \mathrm{C}[30]$.

The hydro-geothermal energy valorisation was made by adapting the already existing district heating system which is operated by Govora Electro-Thermal Trading Company which is owned by the Vâlcea County Council.

Initially, geothermal energy was used in the local hotels and treatment centres, which built their own systems and, after 2002, a project for extending the geothermal grid was initiated in Călimănești town, by using the available supplies of well 1009. The project was initiated using the financial support of the local authorities, with the logistic support of an Austrian company, and later it was developed and commissioned by using European funding programmes [23]. The basic design of this exploitation is presented in Figure 11.

The town energy distribution grid for using the geothermal sources, grafted onto the already existing one, required the building of a thermal power plant close to the place of extraction of the hot water. On the level of the thermal power plant, the heat transfer fluid with a temperature of $85^{\circ} \mathrm{C}$ is achieved by plate heat exchangers. The plant uses a heat exchanger which works permanently, covering the demand of thermal energy for preparing the running hot water, and a heat exchanger that works only during the cold season, when the heating system is put into operation. In order to cover the peak demand, the hot water boilers using liquid fuel were kept. The amount of thermal energy coming from geothermal sources distributed through the local grid in 2011 was, according to the official data supplied by the town administration, of $8159 \mathrm{Gcal}(9.482 \mathrm{GWh})$. To this amount, should be added the thermal energy used in the private circuit of the balneary treatment centres and the pools owned by several hotels. Considering the fluctuations caused by the number of tourists and the season, it was estimated that these grids use an average amount of $7500 \mathrm{Gcal}(8723 \mathrm{GWh})$.

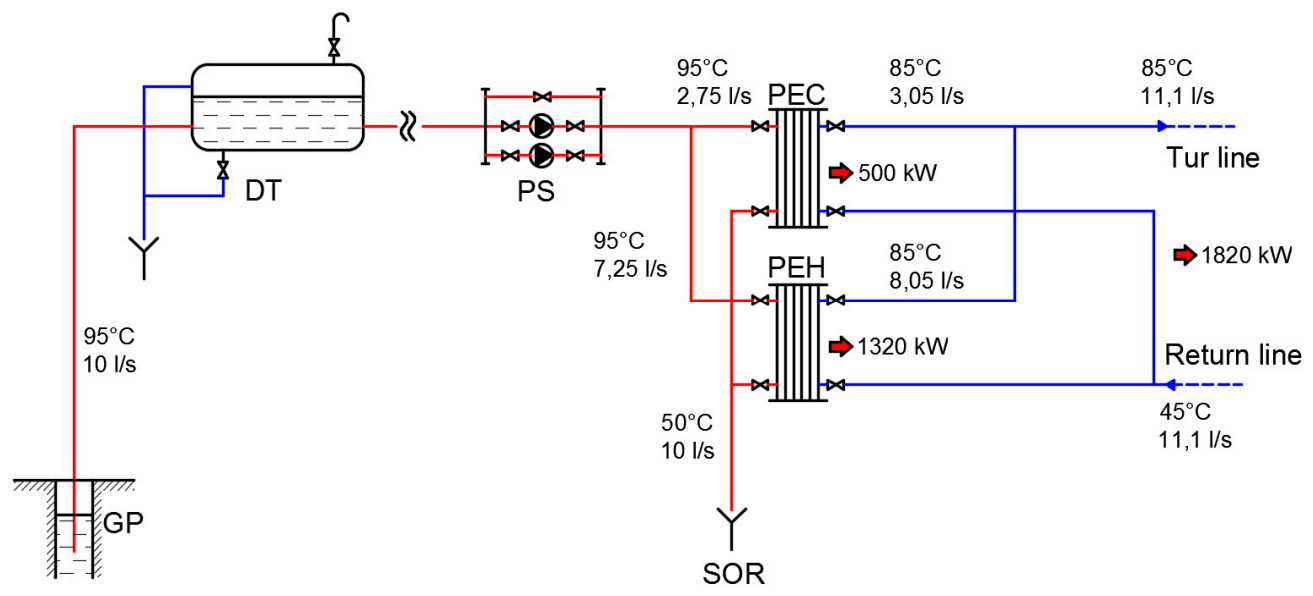

Figure 11. The basic design of the geothermal power station, adapted from [30] with the permisison from (C) General Association of Engineers in Romania, 2016; where: DT—degassing tank; PS-Pumping Station; GP-Geothermal; PEC—Plate exchanger for hot water consumption; PEH-Plate exchanger for hot water heating; SOR-Spill into Olt River. 
Călimănești community is connected to the natural gas pipeline network, which is used to ensure the thermal energy necessary for cooking in the blocks of flats as well as for cooking and heating in some of the private homes. According to the official data, in 2011 the natural gas consumption was around 32,000 cubic meters. For an average calorific power of $10.912032 \mathrm{kWh} / \mathrm{m}^{3}$ of the gas supplied in the area by Distrigaz Sud Company, there was a consumption of 349.185 MWh.

Another part of Călimănești community uses heating systems based on wood. We are talking here about private homes, certain small accommodation establishments and certain administrative units pertaining to them. In order to be considered as renewable source, according to the legislation in use (Order of the Ministry of Environment and Forests no. 1342 completed by the Order no. 85/2013 of the minister of Environment and Climate Change) wood mass used in these individual homes has to be certified as biomass. In the case of this analysis, this condition is considered to be fulfilled.

Usually, a private home uses between 10 and $12 \mathrm{~m}^{3}$ of wood per year for heating. Considering the relatively mild climate of this area, a quantity of $10.5 \mathrm{~m}^{3}$ of biomass per year is being considered. The total amount of energy from biomass is of 2,750,000 kWh.

The complete energy analysis of a community also includes transport and fuel used for this purpose, it involves determining the amounts coming from outside the community and the ones produced within the community borders, and determining if these amounts come from classical sources or from biofuels. According to the intention of the user and to the purpose of the analysis, the transportation can be excluded from the energy assessment, as most of it is based on petroleum fuels which are provided by the major suppliers. The local administration has influence only on the municipal fleet and partially on the internal public transportation, and no influence on the population. In Călimănești there is the local transportation system which connects Călimănești town to the components communities: Păuşa, Jiblea nouă, Jiblea Veche) and both alternatives will be analyzed.

Once all the data have been gathered, and given the hypotheses mentioned above, we can determine the energy autonomy rate of the community. The analysis will not be carried out separately on each field of activity (we leave that for a later stage or for another user of the methodology), but on the town as a whole. The results achieved are presented in Figures 12 and 13.

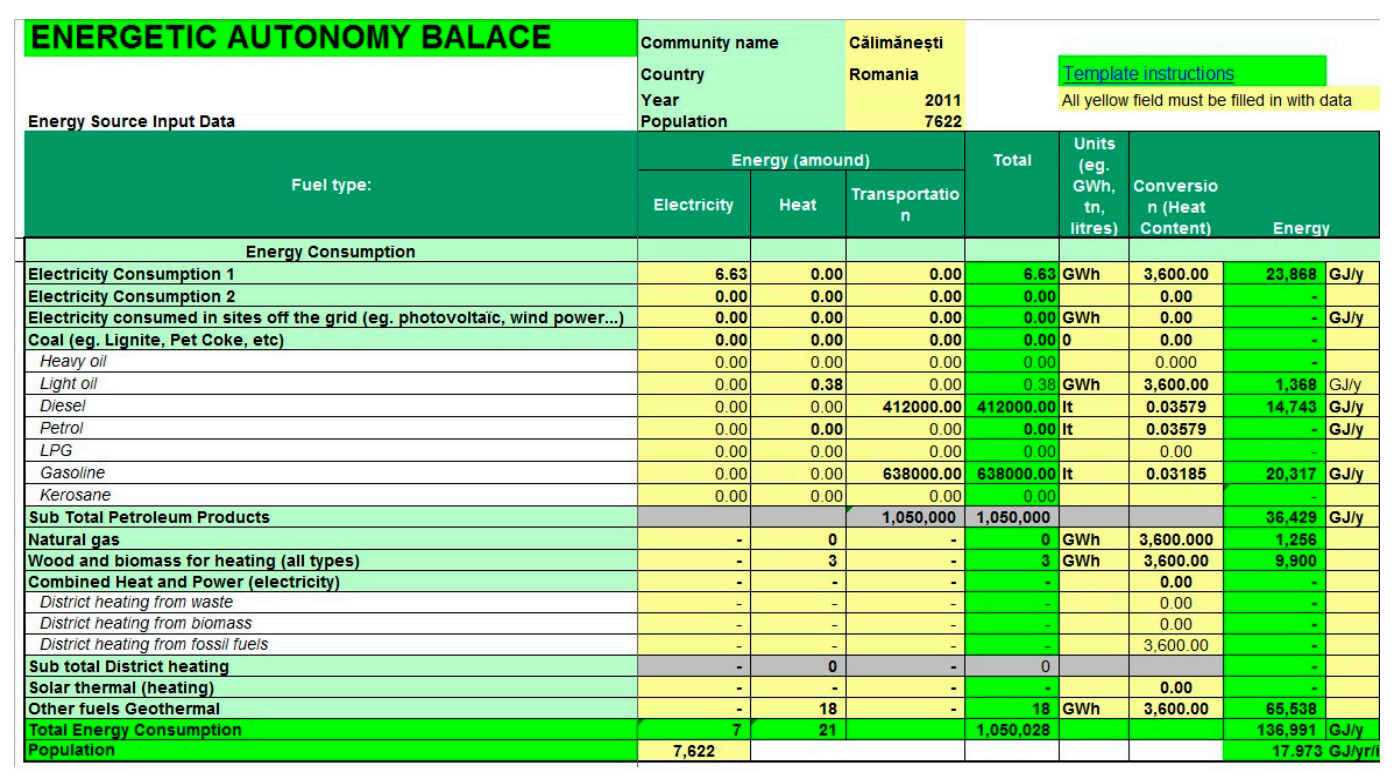

Figure 12. Energy consumption of Calimănești town. 


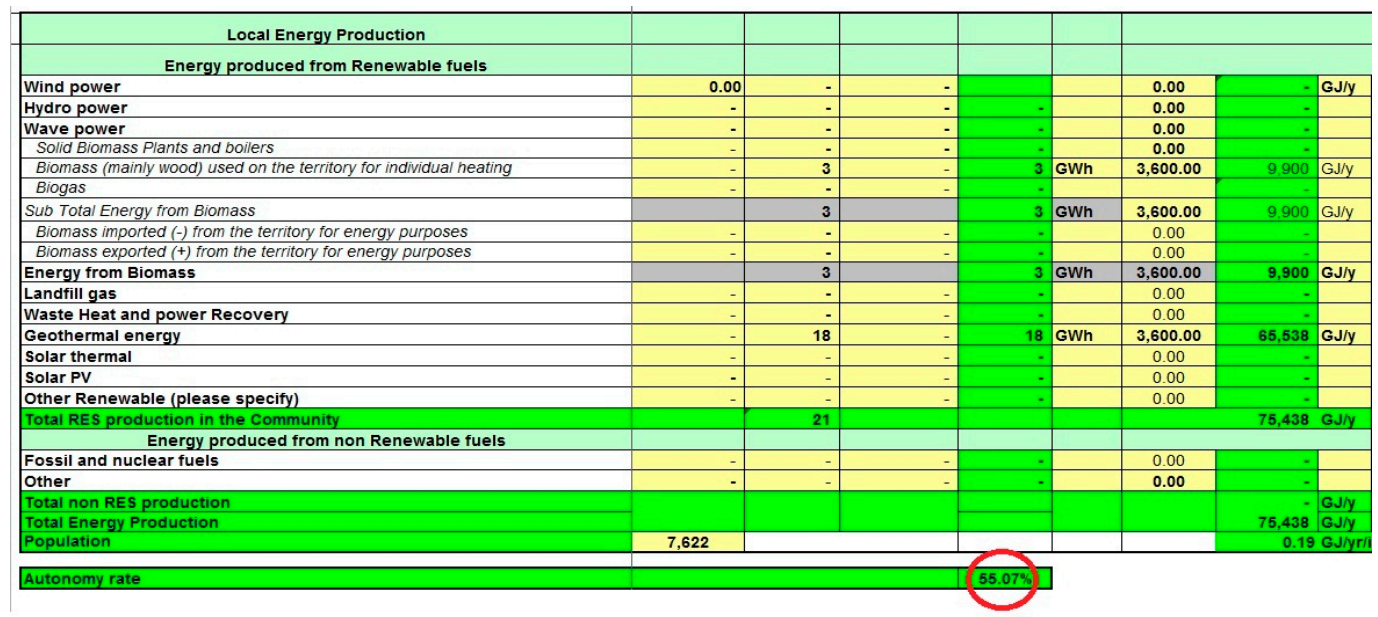

Figure 13. Energy production and the autonomy rate of Călimănești.

\section{Results}

As we can observe, the energy autonomy rate is of $55.07 \%$. The contribution of the geothermal energy to this percentage is of $86.9 \%$. When the fuel necessary for transportation is included, the percentage of the energy autonomy rises to $74.01 \%$.

The use of geothermal resources brought significant benefits for the budget of the population, the amount of the thermal energy bill dropping significantly. Thus, while the price of the thermal energy produced in Romania using classical methods was of 50 euro, and in Bucharest it was around 300 euro/gigacalorie ( 0.258 euro / $\mathrm{kWh})$, in Călimănesti the population linked to the local grid based on geothermal energy paid 25-30 euro/gigacalorie (0.022-0.026 euro/ $\mathrm{kWh})$.

The effect on the environment quality is also important, the use of geothermal energy leading to a decrease of the greenhouse gases with approximately 4500 tons of $\mathrm{CO}_{2}$, gases which would have been emitted in order to generate the same amount of energy based on fossil fuels [18].

Despite these advantages, the exploitation system for the geothermal energy is not perfect. Designed and installed gradually, it requires improvement in order to solve at least two important problems:

- As the temperature of the returning heat transfer fluid is around $45^{\circ} \mathrm{C}$, the geothermal water can only be cooled down to a certain temperature situated somewhere around this value, before being discharged to the Olt river. This prevents the thermal potential of the geothermal water from being fully used, and it also causes a negative impact on the ecosystem in the discharge area.

- The second problem is connected to the use of the gases which accompany the geothermal water, gases with a content of approximately $85 \%$ methane [31,32]. The gases are eliminated from the thermal water before using it by means of a standard procedure, directly into the atmosphere, fact which, on one hand leads to the waste of a certain energetic potential, and on the other hand affects the environment.

Concerned about ensuring a clean environment, and considering the tourism industry on which the town development was based, the local authorities tried to find solutions for the two problems as well as to find the pertaining financial sources. Reinjecting the used waters into the deposit [33-35] would eliminate the environmental problem and would allow a faster regeneration of the aquifer, regeneration which, in the given conditions, takes place due to the reduced water catchments during the summer months. However, the costs of a restitution drilling are appreciable, and a more feasible solution is represented by the suggestion of certain specialists [25] consisting of the use of a water/water heat pump with mechanical compression. It would allow the use of the residual thermal energy and it would lower the water temperature to approximately $30^{\circ} \mathrm{C}$ before discharging it into Olt River. 
Considering the second problem, from an economic point of view [36,37] it would be beneficial to separate and use the gases which accompany the thermal waters, fact which would increase the amount of energy from geothermal sources by $20 \%$.

So far, the exploitation of the geothermal deposit has not been extended, but the officials are considering reopening the drilling in the case of well 1010 at depths over $3200 \mathrm{~m}$ in order to get a better flow and higher temperature and to supplement the thermal energy supply used in Călimănești.

The deficiencies mentioned during the presentation of the case study prove the importance of adopting the best exploitation technologies, the need of a larger vision on the way the geothermal resources are used and-the most important point-this exploitation should be carried out in a sustainable way, without the risk to deplete the geothermal deposit.

\section{Conclusions}

According to the present legislation, all city halls must have in their setup a position of energy manager, which must know, monitor and develop strategies in this domain. Successful energetic management entails, first of all, a good knowledge of the actual needs of the community, of the manner in which the energy is ensured and utilized. Turning the renewable sources of energy into an advantage constitutes a huge potential for sustainable development and for energetic autonomy for the communities, a potential which must be taken into consideration when developing the energetic strategy.

The paper provides a particular methodology for the energetic evaluation of the towns, but which can be also used to even larger areas. Applying this methodology allows a multitude of tests and evaluations. For instance, we can determine the percentage of a certain type of energy in the total consumption, the percentage of a certain type of fuel out of all the fuels used, the report of consumption on different economic sectors or the percentage of a certain sector out of the total consumption of energy, etc., including the weight of renewable energy used by the respective community.

Despite its great potential, geothermal energy is too little exploited because of the technological, legislative and financial difficulties. It is estimated that during the next 30 years the technical problems will be solved and countries without a tradition in this field will be able to use their own geothermal energy with competitive costs. The energy analysis of Călimănești town emphasized the way in which the renewable sources, geothermal in the mentioned case, can ensure the community an important rate of energy autonomy, comfort as well as financial stability for its inhabitants. The methodology presented here is an important tool for the energy analysis of any community and for drawing up plans for sustainable development.

The climate changes and the dependence on the energy imports from outside its borders are two strong reasons which made the European Union become extremely active in developing the exploitation of renewable energy.

Acknowledgments: The paper is a result of the project Network of small RURal communities for ENERgetic-neutrality, founded by Intelligent Energy Europe, acronym RURENER, and the authors gratefully acknowledge for the support of the partners and especially of the colleague Konstantinos Sioulas.

Author Contributions: Liliana Topliceanu made the research on the field and wrote the article. Gabriel Petru Puiu made the graphical representations and contributed to the pagination of the material.

Conflicts of Interest: The authors declare no conflict of interest.

\section{References}

1. Anzellini, S.; Dewaele, A.; Mezouar, M.; Loubeyre, P.; Morard, G. Melting of iron at Earth's inner core boundary based on fast X-ray diffraction. Science 2013, 340, 464-466. [CrossRef] [PubMed]

2. National Geographic Society, Encyclopedic Entry, Crust. Available online: http://nationalgeographic.org/ encyclopedia/crust/ (accessed on 5 June 2016). 
3. Bertani, R. Geothermal Energy: An overview on resources and potential. In Proceedings of the Geothermal Energy in ECA Region Countries, GeoFunds-IGA geothermal Workshop “Turkey 2009”, Istanbul, Turkey, 16-19 February 2009.

4. Dickson, M.H.; Fanelli, M. Geothermal Energy: Utilization and Technology; United Nations Educational, Scientific and Cultural Organization (UNESCO) Publishing: Paris, France, 2003.

5. Dickson, M.H.; Fanelli, M. What is Geothermal Energy?; United Nations Educational, Scientific and Cultural Organization Publishing (UNESCO): Paris, France, 2004. Available online: http://unesdoc.unesco.org/ images/0013/001332/133254e.pdf (accessed on 15 January 2016).

6. Bertani, R. Geothermal Power Generation in the World 2010-2014 Update Report. In Proceedings of the World Geothermal Congress 2015, Melbourne, Australia, 19-25 April 2015.

7. European Commission. Integration of Renewable Energy in Europe; European Commission: Brussels, Belgium, 2014.

8. European Geothermal Energy Council. 2014-EGEC Market Report 2013/2014 Update. Available online: http:/ / egec.info/wp-content/uploads/2011/03/EGEC-Market-Report-Update-online.pdf (accessed on 14 December 2015).

9. Hurter, S.; Haenel, R. Atlas of Geothermal Resources in Europe; Office for Official Publications of the European Communities: Luxembourg, Luxembourg, 2002.

10. European Union. EU Energy in Figures—Statistical Pocketbook 2015; Publications Office of the European Union: Luxembourg, Luxembourg, 2015.

11. Eurostat Statistics. Available online: http://ec.europa.eu/eurostat/web/energy/data/database (accessed on 10 January 2016).

12. Hess, D.J. Sustainability transitions: A political coalition perspective. Res. Policy 2014, 43, 278-283. [CrossRef]

13. Rybach, L. Geothermal power growth 1995-2013-A comparison with other renewables. Energies 2014, 7, 4802-4812. [CrossRef]

14. D'Alessandro, W.; Brusca, L.; Kyriakopoulos, K.; Michas, G.; Papadakis, G. Hydrogen sulphide as a natural air contaminant in volcanic/geothermal areas: The case of Sousaki, Corinthia (Greece). Environ. Geol. 2009, 57, 1723-1728. [CrossRef]

15. Special Report on Renewable Energy Sources and Climate Change Mitigation. Available online: http: //srren.ipcc-wg3.de/report/IPCC_SRREN_Ch04.pdf/view (accessed on 26 January 2016).

16. Kagel, A.; Bates, D.; Gawell, K. A Guide to Geothermal Energy and the Environment Geothermal Energy Association. 2007. Available online: http://www.geo-energy.org/reports/Environmental\%20Guide.pdf (accessed on 14 December 2015).

17. DiPippo, R. Geothermal energy Electricity generation and environmental impact. Energy Policy 1991, 19, 798-807. [CrossRef]

18. Fridleifsson, I.B.; Bertani, R.; Huenges, E.; Lund, J.W.; Ragnarsson, A.; Rybach, L. The possible role and contribution of geothermal energy to the mitigation of climate change. In Proceedings of the IPCC Scoping Meeting on Renewable Energy Sources, Luebeck, Germany, 21-25 January 2008; p. 36.

19. Deichmann, N.; Giardini, D. Earthquakes induced by the stimulation of an enhanced geothermal system below Basel (Switzerland). Seismol. Res. Lett. 2009, 80, 784-798. [CrossRef]

20. Geothermal District Heating (GeoDH) Project. Available online: http:/ /geodh.eu/ (accessed on 5 December 2015).

21. Böttger, D.; Götz, M.; Lehr, N.; Kondziella, H.; Bruckner, T. Potential of the power-to heat technology in district heating grids in Germany. Energy Procedia 2014, 46, 246-253. [CrossRef]

22. Bendea, C.; Antal, C.; Rosca, M. 2015-Geothermal Energy in Romania: Country Update 2010-2014. In Proceedings of the World Geothermal Congress, Melbourne, Melbourne, Australia, 19-25 April 2015.

23. Burchiu, N.; Burchiu, V.; Gheorghiu, L. Centralized Heat Supply Based on Geothermal Resources, in the City Călimăneşti-Vâlcea County (in Romanian). Available online: http:/ /mmut.mec.upt.ro/mh/Conferinta_ Buc/Lucrari/S3/S3L10.pdf (accessed on 18 February 2016).

24. Rosca, M.; Antics, M.; Sferle, M. Geothermal Energy in Romania. Country Update 2000-2004. In Proceedings of the World Geothermal Congress 2005, Antalya, Turkey, 24-29 April 2005.

25. Polizu, R.; Hanganu-Cucu, R. A Case Study of Good Practice in Ground Source Heating/Cooling: Auto Showroom, Offices and Workshop VW Bucharest Romania. 2015. Available online: http://www.wrec.ro/ wp-content/uploads/2015/08/S6.2-R.-Polizu-R.-Hanganu-Cucu.pdf (accessed on 12 November 2015). 
26. Romania-State of the Art of Country and Local Situation. 2014. Available online: http://www.southeasteurope.net/ (accessed on 12 November 2015).

27. Rurener, Energetic Neutrality Template. 2010. Available online: http://rurener.eu/files/2010/07/Template_ instructions_excel.pdf (accessed on 20 December 2015).

28. Topliceanu, L.; Sioulas, K. Rural Development trough the Optimization of the Renewable Energy Potential. Environ. Eng. Manag. J. 2015, 14, 321-330.

29. Development Strategy Călimăneşti Town 2014-2020. (Strategia de Devoltare a Orasului Calimanesti 2014-2020.). 2014. Available online: http://www.primaria-calimanesti.ro/anunturi/comunicate/item/392strategia-de-dezvoltare-a-orasului-calimanesti-2014--2020.html (accessed on 12 November 2015).

30. Dimitriu, S.; Bianchi, A.M.; Băltăreţu, F. The efficiency of An Urban of Heat Supply by Using Geothermal Energy (in Romanian). Bulletin of General Association of Engineers in Romania (AGIR), Journal nr. 4/2010. Available online: http:/ /www.agir.ro/buletine/824.pdf (accessed on 12 December 2015).

31. Renewable Energies Transfer System. Best Practice Case Study: Installation for the Valorization of the Geothermal Resources from Calimanesti Town Valcea County, South-West Oltenia Region, Romania. Available online: http:/ / www.rets-project.eu (accessed on 14 December 2015).

32. Roşca, M.; Antics, M. Current status of geothermal energy utilization in Romania. In Proceedings of the International Workshop on Geothermal Energy Resources in Central and Eastern European Countries, State-of-the-Art and Possibilities for Development, Zakopane, Poland, 13-17 September 2004.

33. Huber, M.; Roger, A.; Hamacher, T. Optimizing long-term investments for a sustainable development of the ASEAN power system. Energy 2015, 88, 180-193. [CrossRef]

34. Malafeh, S.; Sharp, B. Role of royalties in sustainable geothermal energy development. Energy Policy 2015, 85, 235-242. [CrossRef]

35. Pellizzone, A.; Agnes Allansdottir, A.; De Franco, R.; Muttoni, G.; Manzella, A. Exploring public engagement with geothermal energy in southern Italy: A case study. Energy Policy 2015, 85, 1-11. [CrossRef]

36. Franco, A.; Vaccaro, M. A combined energetic and economic approach for the sustainable design of geothermal plants. Energy Convers. Manag. 2014, 87, 735-745. [CrossRef]

37. Hähnlein, S.; Bayer, P.; Ferguson, G.; Blum, P. Sustainability and policy for the thermal use of shallow geothermal energy. Energy Policy 2013, 59, 914-925. [CrossRef]

(C) 2016 by the authors; licensee MDPI, Basel, Switzerland. This article is an open access article distributed under the terms and conditions of the Creative Commons Attribution (CC-BY) license (http://creativecommons.org/licenses/by/4.0/). 